\title{
Assessment of Heavy Metal Enrichment and the Degree of Contamination in Coastal Sediment from South East Coast of Tamilnadu, India
}

\author{
Sivakumar $\mathbf{S}^{1}$, Chandrasekaran $\mathbf{A}^{2}$, Balaji $\mathbf{G}^{3}$ and Ravisankar $\mathbf{R}^{3}$ \\ ${ }^{1}$ Department of Physics, Mailam Engineering College, Mailam 604304, Tamilnadu, India \\ ${ }^{2}$ Department of Physics, SSN College of Engineering, Kalavakkam, Chennai 603110, Tamilnadu, India \\ ${ }^{3}$ Post Graduate and Research Department of Physics, Government Arts College, Thiruvanamalai 606603, Tamilnadu, India
}

Corresponding author: Ravisankar R, Post Graduate and Research Department of Physics, Government Arts College, Thiruvanamalai 606603, Tamilnadu, India, Tel: +91-9840807356; E-mail: ravisankarphysics@gmail.com

Received date: July 04, 2016; Accepted date: July 19, 2016; Published date: July 22, 2016

Copyright: (c) 2016 Sivakumar S, et al. This is an open-access article distributed under the terms of the Creative Commons Attribution License, which permits unrestricted use, distribution, and reproduction in any medium, provided the original author and source are credited.

Citation: Sivakumar S, Chandrasekaran A, Balaji G, et al. Assessment of Heavy Metal Enrichment and the Degree of Contamination in Coastal Sediment from South East Coast of Tamilnadu, India. J Heavy Met Toxicity Dis. 2016, 1:2.

\section{Abstract}

Assessment of heavy metals in coastal sediments from Thazhankuda to Kodiyakkarai along the East Coast of Tamilnadu, India was carried out using Energy dispersive X-ray fluorescence (EDXRF) technique with the computation of different pollution indices. The mean order of metal concentration is $\mathrm{Al}>\mathrm{Fe}>\mathrm{Ca}>\mathrm{K}>\mathrm{Mg}>\mathrm{Ti}>\mathrm{Mn}>\mathrm{Cr}>\mathrm{V}>\mathrm{Zn}>\mathrm{Ni}>\mathrm{Co}$ in the study area. The locations of Pichavaram (CPM), Tharangambadi (TRGB) and Karaikal (PKK) were found to be moderately polluted by heavy metals due to anthropogenic activities. The pollution indices such as Contamination factor (CF), Pollution load index (PLI), Contamination degree $\left(C_{d}\right)$, modified degree of contamination $\left(\mathrm{mC}_{\mathrm{d}}\right)$, Potential contamination index $\left(C_{p}\right)$ and potential ecological risk index (RI) were used for the metal enrichment and contamination status. The CF and PLI value of the present work indicating that the sediments are not polluted by heavy metals. The calculated Contamination degree $\left(C_{d}\right)$, modified degree of contamination $\left(\mathrm{mC}_{\mathrm{d}}\right)$, Potential contamination index $\left(C_{p}\right)$ and potential ecological risk index (RI) of the studied metals indicated that the study area does not posed high risk to local environments.

Keywords: Sediment; EDXRF; Pollution indices; Potential ecological risk

\section{Introduction}

Human activities on land, in the water and air contribute the contamination of seawater and organisms with potentially toxic substances [1,2]. A high level of land use change has led to a strong risk of heavy metal contamination in coastal ecosystems [2-5]. Inappropriate land use has been discussed as a factor that can affect coastal ecosystem health over many years, and clearly, changes in how land is used to directly reflect changing human activities in recent decades [6-11]. Marine pollution is a serious concern in worldwide. Coastal and estuarine regions are considered as the important sinks for the persistent of pollutants. Accumulation of heavy metals occurs in sediment in aquatic environments by biological and geochemical mechanisms and become toxic to sedimentdwelling organisms and fish, resulting in death, reduced growth, or in impaired reproduction and lower species diversity [12]. Sources of metals in aquatic sediments are natural or anthropogenic sources $[13,14]$. Sediment pollution by heavy metals has been regarded as a critical problem in marine environments because of their toxicity, persistence and bioaccumulation. So it is necessary to investigate the distribution and pollution degree of heavy metal, in order to interpret the mechanism of transportation and accumulation of pollutants and to provide basic information for coast utilization and supervision $[15,16]$.

The present study investigated the assessment of heavy metal pollution in the sediments from Thazhankuda to kodiyakkarrai of the East Coast of Tamilnadu, India. The study area chosen for the heavy metals analysis due to a variety of industrial activities (such as metal smelting, pharmaceuticals etc.) and agriculture activities (which include maize, cassava, sugarcane and vegetables farming) takes place and may enhance the pollution level. These activities may release toxic and potentially hazards to the environment of the study area. So this research is geared up to assess the metal pollution and influence of sources from the toxic metals in the sediments from East Coast of Tamilnadu. The main objective of this work is [1] to determine concentrations of metals present in sediments using EDXRF technique [2] to evaluate the metal contamination of sediments using the pollution indices [3] to identify the sources of heavy metals influenced by of natural and/or anthropogenic [4] to report the findings. 


\section{Materials and Methods}

\section{Study area}

Sediment samples were collected from Thazhankuda to Kodiyakkaraialong the Bay of Bengal coastline during the premonsoon condition. Table 1 lists geographical latitude and longitude of the sampling locations of the study area.

Table 1: The geographical latitude and longitude for the sampling locations at the study area.

\begin{tabular}{|c|c|c|c|c|}
\hline $\begin{array}{l}\text { S. } \\
\text { No } \\
\text {. }\end{array}$ & $\begin{array}{l}\text { Sample } \\
\text { ID }\end{array}$ & Latitude(N) & $\begin{array}{l}\text { Longitude } \\
\text { (E) }\end{array}$ & Location \\
\hline 1 & CTK & $11^{\circ} 46^{\prime} 7.06^{\prime \prime}$ & $79^{\circ} 48^{\prime} 40.40^{\prime \prime}$ & Thazhankuda \\
\hline 2 & CDM & $11^{\circ} 43^{\prime} 46.84^{\prime \prime}$ & $79^{\circ} 48^{\prime} 11.39^{\prime \prime}$ & Devanampattinum \\
\hline 3 & COT & $11^{\circ} 43^{\prime} 5.30^{\prime \prime}$ & $79^{\circ} 48^{\prime} 11.73^{\prime \prime}$ & Singarrathoppu \\
\hline 4 & CAP & $11^{\circ} 35^{\prime} 11.38^{\prime \prime}$ & $79^{\circ} 47^{\prime} 0.66^{\prime \prime}$ & Ayyampet \\
\hline 5 & CSP & $11^{\circ} 32^{\prime} 56.29^{\prime \prime}$ & $79^{\circ} 46^{\prime} 48.59^{\prime \prime}$ & Samiyarpet \\
\hline 6 & CPT & $11^{\circ} 31^{\prime} 23.26^{\prime \prime}$ & $79^{\circ} 47^{\prime} 15.73^{\prime \prime}$ & Parangipet \\
\hline 7 & CPM & $11^{\circ} 24^{\prime} 41.34^{\prime \prime}$ & $79^{\circ} 50^{\prime} 13.01^{\prime \prime}$ & Pichavaram \\
\hline 8 & KDM & $11^{\circ} 22^{\prime} 53.02^{\prime \prime}$ & $79^{\circ} 50^{\prime} 28.13^{\prime \prime}$ & Kodiyampalayam \\
\hline 9 & NPZ & $11^{\circ} 19^{\prime} 57.07^{\prime \prime}$ & $79^{\circ} 51^{\prime} 2.77^{\prime \prime}$ & Pazhaiyar \\
\hline 10 & $\mathrm{NSI}$ & $11^{\circ} 13^{\prime} 48.86^{\prime \prime}$ & $79^{\circ} 52^{\prime} 7.23^{\prime \prime}$ & Sirkazhi \\
\hline 11 & NPB & $11^{\circ} 8 ' 34.55^{\prime \prime}$ & $79^{\circ} 52^{\prime} 42.17^{\prime \prime}$ & Poombukar \\
\hline 12 & TRGB & $11^{\circ} 1^{\prime} 31.97^{\prime \prime}$ & $79^{\circ} 52^{\prime} 53.12^{\prime \prime}$ & Tharangambadi \\
\hline 13 & PKK & $10^{\circ} 54^{\prime} 59.40^{\prime \prime}$ & $79^{\circ} 52^{\prime} 12.23^{\prime \prime}$ & Karaikal \\
\hline 14 & NGR & $10^{\circ} 49^{\prime} 16.46^{\prime \prime}$ & $79^{\circ} 52^{\prime} 21.05^{\prime \prime}$ & Nagore \\
\hline 15 & NAP & $10^{\circ} 44^{\prime} 42.24^{\prime \prime}$ & $79^{\circ} 52^{\prime} 33.60^{\prime \prime}$ & Akkaraipettai \\
\hline 16 & VLK & $10^{\circ} 41^{\prime 2} 2.93^{\prime \prime}$ & $79^{\circ} 52^{\prime} 35.61^{\prime \prime}$ & Velankanni \\
\hline 17 & TPI & $10^{\circ} 37^{\prime} 39.79^{\prime \prime}$ & $79^{\circ} 52^{\prime} 49.71^{\prime \prime}$ & Thirupoondi \\
\hline 18 & VKT & $10^{\circ} 33^{\prime} 16.64^{\prime \prime}$ & $79^{\circ} 53^{\prime} 15.85^{\prime \prime}$ & Vettaikaranthoppu \\
\hline 19 & VED & $10^{\circ} 22^{\prime} 58.20^{\prime \prime}$ & $79^{\circ} 55^{\prime} 37.80^{\prime \prime}$ & Vedaranium \\
\hline 20 & KODI & $10^{\circ} 19^{\prime} 55.85^{\prime \prime}$ & $79^{\circ} 58^{\prime} 1.53^{\prime \prime}$ & Kodiyakkarai \\
\hline
\end{tabular}

Recent industry developments during the last two decades in Cuddalore, Karaikal and Nagapattinam coastal towns include offshore oil production, chemical, fertilizer processing plants and more than 150 small scale industries, all located in this region makes attention for sediment analysis. The recent development of a minor harbor in Nagapattinam town is very important because it acts as the main fishing harbor with heavy movement of fishing and naval vessels in this region. The study area is also drained by the tributaries of river Cauvery which runs through many industrial towns and its tributaries, i.e. rivers Puravandayanar, Vettar, Uppanar pass through the agricultural belt of Tamilnadu state and finally drain into the Bay of Bengal in this coastal sector [17].

\section{Sample collection and preparation}

Sediment samples were collected by a Peterson grab sample from a distance of $10 \mathrm{~m}$ inside the sea (parallel to the shoreline) along the 20 locations during May 2012. These samples were collected pre-monsoon season, when sediment texture and ecological conditions can be clearly observed, when erosional activities are predominant, and sediments were not transported from the river and estuary towards the beach and marine [18]. Figure 1 shows the location map of the study area. Peterson grab sampler is ideal for near shore sampling with sea bottom having sand, silt or gravel type of sediments. This is the universal method of sediment sample collection for sea bottom sediment sampling at near shore environment [19-21]. Uniform quantity of sediment samples were collected from all the sampling locations. Around $25 \mathrm{~cm}$ thick sub-surface samples from the sea bed were collected by the grab sampler. The top sediment layer was scooped with an acid washed plastic spatula. From this $10 \mathrm{~cm}$ thick sediment layer was sampled from the middle of the grab. The collected samples were immediately transferred to polythene bags and refrigerated at $-4^{\circ} \mathrm{C}$ until analysis.

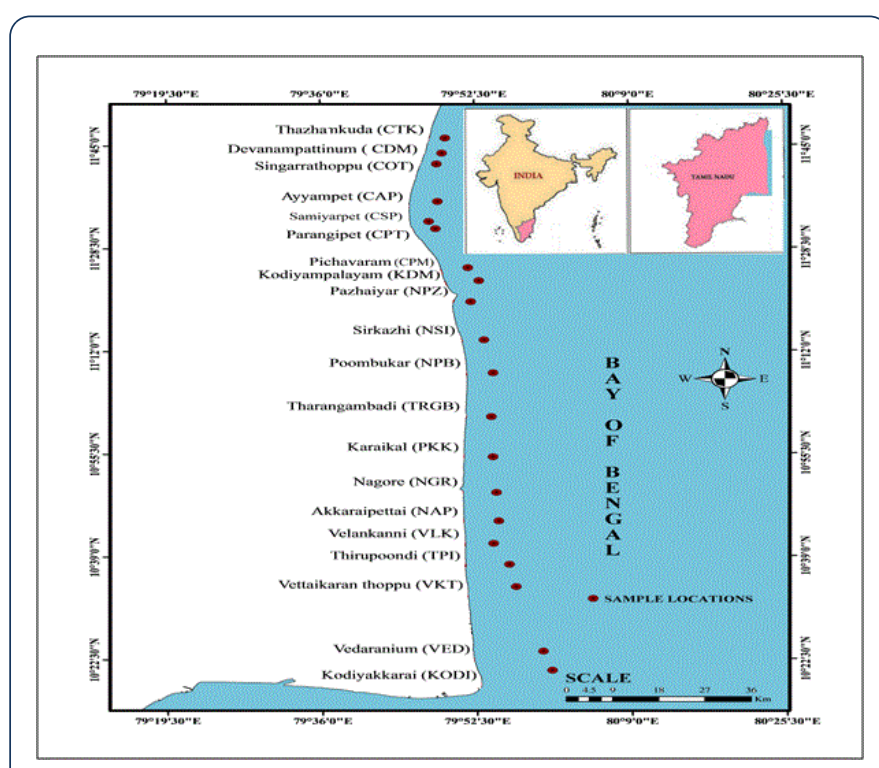

Figure 1: Location map.

The samples were dried at $105^{\circ} \mathrm{C}$ for $2 \mathrm{~h}$ to a constant weight and sieved using a $63 \mu \mathrm{m}$ sieve in order to identify the geochemical concentrations [22-24]. The grain size of $<63 \mu \mathrm{m}$, presents several advantages: (1) heavy metals are mainly linked to silt and clay; [2] this grain size is like that of the suspended matter in water; and [3] it has been used in many studies on heavy metal contamination. The samples were then ground to a fine powder using an agate mortar. All powder samples were stored in a desiccator until they were analyzed. One gram of the fine ground sample and $0.5 \mathrm{~g}$ of boric acid $\left(\mathrm{H}_{3} \mathrm{BO}_{3}\right)$ were mixed. The mixture was thoroughly grinded and pressed into a pellet of $25 \mathrm{~mm}$ diameter using a hydraulic press (20 tons) [25]. 


\section{EDXRF technique}

The prepared pellets were analysed using the EDXRF available at Environmental and Safety Division, Indira Gandhi Centre for Atomic Research (IGCAR), Kalpakkam, Tamilnadu. The instrument used for this study consists of an EDXRF spectrometer of model EX-6600SDD supplied by Xenemetrix, Israel. The spectrometer is fitted with a side window X-ray tube $(370 \mathrm{~W})$ that has Rhodium as anode. The power specifications of the tube are 3-60 kV; $10-5833 \mu \mathrm{A}$. Selection of filters, tube voltage, sample position and current are fully customizable. The detector SDD $25 \mathrm{~mm}^{2}$ has an energy resolution of $136 \mathrm{eV} \pm 5 \mathrm{eV}$ at $5.9 \mathrm{keV} \mathrm{Mn} \mathrm{X-ray} \mathrm{and} 10$ sample turret enables keeping and analysing 10 samples at a time. The quantitative analysis is carried out by the In-built software nEXT. A standard soil (NIST SRM 2709a) was used as reference material for standardizing the instrument. This soil standard obtained from a follow field in the central California San Joaquin valley. The soil standard (reference material) (NIST SRM 2709a) analysis value are given in Table 2 which reports the certified values with measured EDXRF and its shows that they are well agreement with each other.

Table 2: Analysis of soil standard-NIST SRM 2709a by EDXRF $\left(\mathrm{mg} / \mathrm{kg}^{-1}\right)$.

\begin{tabular}{|l|l|l|}
\hline Element & Certified Values & EDXRF values \\
\hline $\mathrm{Mg}$ & 14600 & $14900 \pm 1000$ \\
\hline $\mathrm{Al}$ & 72100 & $68400 \pm 2300$ \\
\hline $\mathrm{K}$ & 20500 & $19100 \pm 700$ \\
\hline $\mathrm{Ca}$ & 19100 & $16500 \pm 500$ \\
\hline $\mathrm{Ti}$ & 3400 & $3100 \pm 100$ \\
\hline $\mathrm{Fe}$ & 33600 & $33900 \pm 1200$ \\
\hline $\mathrm{V}$ & 110 & $112.1 \pm 4.01$ \\
\hline $\mathrm{Cr}$ & 130 & $568.2 \pm 19.85$ \\
\hline $\mathrm{Mn}$ & 529 & $12.8 \pm 0.55$ \\
\hline $\mathrm{Co}$ & 12.8 & $69.3 \pm 2.98$ \\
\hline $\mathrm{Ni}$ & 83 & $127.9 \pm 4.88$ \\
\hline $\mathrm{Zn}$ & 107 & \\
\hline & & \\
\hline
\end{tabular}

\section{Assessment of sediment contamination}

Sediments have the capability to record the history and indicate the degree of pollution. To assess the degree of pollution for giving heavy metal requires that the pollutant metal concentration to be compared with an unpolluted reference material (geochemical background). Absence of background values of metal concentrations in Indian estuarine systems made us to use the reference material. The reference material represents a benchmark to which the metal concentrations in the polluted samples are compared and measured. Many authors have used the average shale values or the average crustal abundance data as reference baselines.
In this work average shale values are used for reference material for background values.

\section{Contamination factor (CF)}

The level of metal contamination can be expressed by the contamination factor (CF). CF is the ratio between the metal content in the sediment to the background value of the metal [26]. It is an effective tool for monitoring the pollution over a period of time and it is calculated as follows

$$
\mathrm{CF}=\frac{\mathrm{C}_{\text {heavy metal }}}{\mathrm{C}_{\text {background }}}
$$

According to Hakanson [27] $\mathrm{CF}<1$ indicates low contamination; $1<\mathrm{CF}<3$ is moderate contamination; $3<\mathrm{CF}<6$ is considerable contamination; and $\mathrm{CF}>6$ is very high contamination.

\section{Pollution load index (PLI)}

The Pollution load index (PLI) represents the number of times by which the heavy metal concentrations in the sediment exceeded the background concentration, and give a summative indication of the overall level of heavy metal toxicity in a particular sample and is determined as the nth root of the product of nCF.

$$
\mathrm{PLI}=\left(\mathrm{CF}_{1} \times \mathrm{CF}_{2} \times \mathrm{CF}_{3} \times \ldots \ldots . . . \times \mathrm{CF}_{\mathrm{n}}\right)^{1 / \mathrm{n}}
$$

Where $\mathrm{CF}_{\mathrm{n}}$ is the $\mathrm{CF}$ value of metal $\mathrm{n}$. It gives simple and comparative means for assessing the heavy metal pollution level in the sediment sample. The PLI values are interpreted into two levels as polluted $(P L I>1)$ and unpolluted $(P L I<1)$ [25-29].

\section{Contamination degree $(\mathrm{Cd})$}

To facilitate pollution control, Hakanson [27] proposed a diagnostic tool named as 'degree of contamination'. $C_{d}$ and it is determined as the sum of the CF for each sample:

$$
\mathrm{C}_{\mathrm{d}}=\sum_{\mathrm{i}=1}^{\mathrm{i}=\mathrm{n}} \mathrm{CF}
$$

The $C_{d}$ is aimed at providing a measure of the degree of overall contamination in surface layers in a particular core or sampling site. Hakanson [27] proposed the classification of the degree of contamination $\left(\mathrm{mC}_{\mathrm{d}}\right)$ in sediments as:

$\mathrm{C}_{\mathrm{d}}<6$ Low degree of contamination

$6<\mathrm{C}_{\mathrm{d}}<12$ Moderate degree of contamination

$12<\mathrm{C}_{\mathrm{d}}<24$ Considerable degree of contamination

$C_{d}>24$ High degree of contamination

\section{Modified degree of contamination $(\mathrm{mCd})$}

The modified degree of contamination was introduced to estimate the overall degree of contamination at a given site according to the formula [30]: 


$$
\mathrm{mC}_{\mathrm{d}}=\frac{\left(\sum_{\mathrm{i}=1}^{\mathrm{i}=\mathrm{n}} \mathrm{CF}\right)}{\mathrm{n}}
$$

Where n-number of analyzed elements and $i=i$ th element (or pollutant) and CF-contamination factor. The modified formula is generalized by defining the degree of contamination $\left(\mathrm{mC}_{\mathrm{d}}\right)$ as the sum of all the contamination factors (CF) for a given set of sediment pollutants divided by the number of analyzed pollutants. Using this generalized formula to calculate the $\mathrm{mC}_{\mathrm{d}}$ allows the incorporation of as many metals as the study may analyses with no upper limit. The expanded range of possible pollutants can thus include both heavy metals and organic pollutants should later be available for the studied samples.

For the classification and description of the modified degree of contamination $\left(\mathrm{mC}_{\mathrm{d}}\right)$ in the sediment, the following gradations are proposed: $\mathrm{mC}_{\mathrm{d}}<1.5$ is nil to a very low degree of contamination; $1.5 \leq \mathrm{mC}_{\mathrm{d}}<2$ is a low degree of contamination; $2 \leq \mathrm{mC}_{\mathrm{d}}<4$ is a moderate degree of contamination; $4 \leq \mathrm{mC}_{\mathrm{d}}<8$ is a high degree of contamination; $8 \leq \mathrm{mC}_{\mathrm{d}}<16$ is a very high degree of contamination; $16 \leq \mathrm{mC}_{\mathrm{d}}<32$ is an extremely high degree of contamination; $\mathrm{mC}_{\mathrm{d}} \leq 32$ is an ultra-high degree of contamination.

\section{Potential contamination index (Cp)}

The potential contamination index can be calculated by the following method.

$$
\mathrm{C}_{\mathrm{p}}=\frac{(\text { Metal) }}{\text { sample Max }}
$$

Where (Metal) sample Max is the maximum concentration of a metal in sediment, and (Metal) Background is the average value of the same metal in a background level. $C_{p}$ values were interpreted as suggested by Dauvalter and Rognerud [31,32] where $C_{p}<1$ indicates low contamination; $1<C_{p}<3$ is moderate contamination; and $\mathrm{C}_{\mathrm{p}}>3$ is severe contamination.

\section{Assessment of potential ecological risk}

Hakanson [27], proposed a method for the potential ecological risk index (RI) to assess the characteristics and environmental behavior of heavy metal contaminants in sediments. The main function of this index is to indicate the contaminant agents and where contamination studies should be prioritized. The potential ecological risk index (RI) is calculated as the sum of all risk factors for heavy metals in sediments, is the monomial potential ecological risk factor, CF is the contamination factor, and $\mathrm{T}_{r}^{\mathrm{i}}$ is the toxic response factor, representing the potential hazard of heavy metal contamination by indicating the toxicity of particular heavy metals and the environmental sensitivity to contamination. According to the standardized toxic response factor proposed by Hakanson $\mathrm{Cr}, \mathrm{As}, \mathrm{Ni}, \mathrm{Pb}$ and $\mathrm{Zn}$ have toxic response factors of $2,5,5,5$ and 1 respectively. The formula of the potential ecological risk index is given below

$$
\begin{aligned}
& \mathrm{E}_{\mathrm{r}}^{\mathrm{i}}=\mathrm{T}_{\mathrm{r}}^{\mathrm{i}} \times \mathrm{CF} \\
& \mathrm{RI}=\sum_{\mathrm{i}=1}^{\mathrm{n}} \mathrm{E}_{\mathrm{r}}^{\mathrm{i}}
\end{aligned}
$$

The terminology used to describe the risk factors and RI was suggested by Hakanson [27], where: $<40$ indicates a low potential ecological risk; $40<\mathrm{Er}<80$ is a moderate ecological risk; $80<\mathrm{Er}<160$ is a considerable ecological risk; $160<\mathrm{Er}<320$ is a high ecological risk and $\mathrm{Er}>320$ is a very high ecological risk. $\mathrm{Rl}<95$ indicates a low potential ecological risk; $95<\mathrm{RI}<190$ is a moderate ecological risk; $190<R \mathrm{R}<380$ is a considerable ecological risk and $\mathrm{RI}>380$ is a very high ecological risk.

\section{Results and Discussions}

Table 3 summarizes the determined heavy metal concentration of the study area by using energy dispersive $X$ ray fluorescence (EDXRF) technique. The concentration of the heavy metal varies from $800-10100 \mathrm{mg} / \mathrm{kg}^{-1}$ for $\mathrm{Mg}$; $38600-70600 \mathrm{mg} / \mathrm{kg}^{-1}$ for $\mathrm{Al} ; 12100-16100 \mathrm{mg} / \mathrm{kg}^{-1}$ for $\mathrm{K}$; $8900-29100 \mathrm{mg} / \mathrm{kg}^{-1}$ for Ca; $1000-21200 \mathrm{mg} / \mathrm{kg}^{-1}$ for Ti; $7900-47100 \mathrm{mg} / \mathrm{kg}^{-1}$ for $\mathrm{Fe}$; $30.1-314.6 \mathrm{mg} / \mathrm{kg}^{-1}$ for V; 38.1-312.6 mg/kg-1 for $\mathrm{Cr}$; $159.8-1171.3 \mathrm{mg} / \mathrm{kg}^{-1}$ for $\mathrm{Mn}$; 2.8-16.6 mg/ $\mathrm{kg}^{-1}$ for $\mathrm{Co}$; $23.9-44 \mathrm{mg} / \mathrm{kg}^{-1}$ for $\mathrm{Ni}$ and $26-87.3$ $\mathrm{mg} / \mathrm{kg}^{-1}$ for $\mathrm{Zn}$. The most abundant metal in the sediments among the heavy metals is found to be Aluminum (Al) [25].

\begin{tabular}{|c|c|c|c|c|c|c|c|c|c|c|c|c|c|}
\hline S.No. & Sample ID & Mg & Al & $\mathrm{K}$ & $\mathrm{Ca}$ & $\mathrm{Ti}$ & $\mathrm{Fe}$ & $\mathbf{v}$ & $\mathrm{Cr}$ & Mn & Co & $\mathrm{Ni}$ & $\mathrm{Zn}$ \\
\hline 1 & CTK & 8800 & 66100 & 15600 & 29100 & 5100 & 22100 & 80.2 & 86.4 & 477.9 & 7.9 & 30.8 & 48.8 \\
\hline 2 & CDM & 4100 & 48200 & 14100 & 14100 & 2100 & 9600 & 35.3 & 38.5 & 187.2 & 3.5 & 24.2 & 26.8 \\
\hline 3 & СОT & 3200 & 47900 & 13300 & 14700 & 2600 & 10600 & 44.6 & 45.6 & 216.1 & 3.8 & 23.9 & 28.1 \\
\hline 4 & CAP & 4400 & 52100 & 13600 & 14300 & 3200 & 14800 & 48.3 & 77.5 & 297.8 & 5.5 & 31.5 & 34.4 \\
\hline 5 & CSP & 4600 & 54000 & 14100 & 15400 & 2700 & 14100 & 45.5 & 66.2 & 271.4 & 5.2 & 29.5 & 36.4 \\
\hline 6 & CPT & 6100 & 60000 & 13900 & 18300 & 3900 & 19700 & 64.8 & 101.8 & 425 & 7.1 & 37.4 & 47.3 \\
\hline
\end{tabular}
The mean order of metal concentration is $\mathrm{Al}>\mathrm{Fe}>\mathrm{Ca}>\mathrm{K}>\mathrm{Mg}>\mathrm{Ti}>\mathrm{Mn}>\mathrm{Cr}>\mathrm{V}>\mathrm{Zn}>\mathrm{Ni}>\mathrm{Co}$ in the study area.

Table 3: Heavy metal concentration $\left(\mathrm{mg} / \mathrm{kg}^{-1}\right)$ in sediments along the East Coast of Tamilnadu, India. 


\begin{tabular}{|c|c|c|c|c|c|c|c|c|c|c|c|c|c|}
\hline 7 & CPM & 9500 & 56700 & 13400 & 17300 & 13800 & 37200 & 223.9 & 232.9 & 745.1 & 12.8 & 41.6 & 69.7 \\
\hline 8 & KDM & 1700 & 42900 & 15500 & 9900 & 1100 & 8600 & 31.1 & 38.1 & 180.9 & 2.9 & 29.1 & 26.4 \\
\hline 9 & NPZ & 800 & 38600 & 13900 & 8900 & 1000 & 7900 & 30.1 & 38.9 & 159.8 & 2.8 & 27.6 & 26 \\
\hline 10 & NSI & 4900 & 48100 & 14900 & 13100 & 2200 & 12500 & 40.7 & 63.6 & 257.1 & 4.6 & 26.9 & 32.8 \\
\hline 11 & NPB & 2400 & 43500 & 15000 & 12000 & 1800 & 11300 & 35.4 & 61.2 & 232.3 & 4 & 25.9 & 29.8 \\
\hline 12 & TRGB & 7900 & 61300 & 15400 & 21000 & 15400 & 38200 & 238.6 & 271.8 & 811.3 & 13 & 42.7 & 65.6 \\
\hline 13 & PKK & 7700 & 70600 & 14300 & 24600 & 21200 & 47100 & 314.6 & 312.6 & 1171.3 & 16.6 & 44 & 87.3 \\
\hline 14 & NGR & 6200 & 56800 & 16100 & 20200 & 5100 & 20000 & 91.1 & 141.2 & 445.1 & 7 & 35.6 & 49.3 \\
\hline 15 & NAP & 8100 & 58000 & 15400 & 18900 & 5200 & 20400 & 77.1 & 120.1 & 451.9 & 7.4 & 34 & 44.6 \\
\hline 16 & VLK & 6700 & 43000 & 12100 & 12200 & 1900 & 10600 & 39.8 & 62.5 & 232.4 & 4 & 25.8 & 32.9 \\
\hline 17 & TPI & 9300 & 59700 & 13600 & 20600 & 10200 & 29900 & 155.7 & 174.7 & 680 & 10.5 & 38.9 & 64.6 \\
\hline 18 & VKT & 7900 & 58300 & 14100 & 20000 & 2600 & 16200 & 52.3 & 105.2 & 342.8 & 5.9 & 33 & 39.1 \\
\hline 19 & VED & 10100 & 57500 & 13000 & 20900 & 5700 & 22500 & 102.5 & 142.9 & 531.3 & 8.1 & 34.3 & 44.7 \\
\hline 20 & KODI & 5300 & 57900 & 13100 & 20300 & 4200 & 18800 & 77 & 121.9 & 433.3 & 6.7 & 32.8 & 38.1 \\
\hline \multicolumn{2}{|c|}{ Average } & 5985 & 54060 & 14220 & 17290 & 5550 & 19605 & 91.4 & 115.2 & 427.5 & 7.0 & 32.5 & 43.6 \\
\hline \multicolumn{2}{|c|}{ Max Value } & 10100 & 70600 & 16100 & 29100 & 21200 & 47100 & 314.6 & 312.6 & 1171.3 & 16.6 & 44 & 87.3 \\
\hline \multicolumn{2}{|c|}{ Bac Value } & 15000 & 88000 & 26600 & 16000 & 4600 & 47200 & 130 & 90 & 850 & 19 & 50 & 95 \\
\hline \multicolumn{2}{|l|}{ Cp } & 0.673 & 0.802 & 0.605 & 1.819 & 4.609 & 0.998 & 2.420 & 3.473 & 1.378 & 0.874 & 0.880 & 0.919 \\
\hline
\end{tabular}

The locations of Karaikkal(PKK), Tharangambadi (TRGB), activities, industrial and urban wastage discharges, dredging, Pichavaram (CPM)are characterized by higher concentrations of $\mathrm{Al}, \mathrm{Ti}, \mathrm{Fe}, \mathrm{V}, \mathrm{Cr}, \mathrm{Mn}$, Co and $\mathrm{Zn}$ when compared with other locations. This may be due to the high tourists' boat activities etc.

The calculated CF values are given in Table 4. and other anthropogenic activities like shipping and harbor

Table 4: Contamination factor (CF), Pollution load index (PLI), Contamination Degree $\left(\mathrm{C}_{\mathrm{d}}\right)$ and Modified Degree of Contamination $\left(\mathrm{mC}_{\mathrm{d}}\right)$ of sediments along the East Coast of Tamilnadu, India.

\begin{tabular}{|c|c|c|c|c|c|c|c|c|c|c|c|c|c|}
\hline S.No. & Sample ID & $\mathbf{M g}$ & K & $\mathrm{Ca}$ & $\mathrm{Ti}$ & $\mathrm{Fe}$ & v & $\mathrm{Cr}$ & Mn & Co & $\mathrm{Ni}$ & $\mathrm{Zn}$ & PLI \\
\hline 1 & CTK & 0.59 & 0.59 & 1.82 & 1.11 & 0.47 & 0.62 & 0.96 & 0.56 & 0.42 & 0.45 & 0.51 & 0.68 \\
\hline 2 & CDM & 0.27 & 0.53 & 0.88 & 0.46 & 0.20 & 0.27 & 0.43 & 0.22 & 0.18 & 0.36 & 0.28 & 0.34 \\
\hline 3 & СOT & 0.21 & 0.50 & 0.92 & 0.57 & 0.22 & 0.34 & 0.51 & 0.25 & 0.20 & 0.35 & 0.30 & 0.37 \\
\hline 4 & CAP & 0.29 & 0.51 & 0.89 & 0.70 & 0.31 & 0.37 & 0.86 & 0.35 & 0.29 & 0.46 & 0.36 & 0.46 \\
\hline 5 & CSP & 0.31 & 0.53 & 0.96 & 0.59 & 0.30 & 0.35 & 0.74 & 0.32 & 0.27 & 0.43 & 0.38 & 0.45 \\
\hline 6 & СРT & 0.41 & 0.52 & 1.14 & 0.85 & 0.42 & 0.50 & 1.13 & 0.50 & 0.37 & 0.55 & 0.50 & 0.60 \\
\hline 7 & CPM & 0.63 & 0.50 & 1.08 & 3.00 & 0.79 & 1.72 & 2.59 & 0.88 & 0.67 & 0.61 & 0.73 & 1.00 \\
\hline 8 & KDM & 0.11 & 0.58 & 0.62 & 0.24 & 0.18 & 0.24 & 0.42 & 0.21 & 0.15 & 0.43 & 0.28 & 0.28 \\
\hline 9 & NPZ & 0.05 & 0.52 & 0.56 & 0.22 & 0.17 & 0.23 & 0.43 & 0.19 & 0.15 & 0.41 & 0.27 & 0.24 \\
\hline 10 & NSI & 0.33 & 0.56 & 0.82 & 0.48 & 0.26 & 0.31 & 0.71 & 0.30 & 0.24 & 0.40 & 0.35 & 0.41 \\
\hline 11 & NPB & 0.16 & 0.56 & 0.75 & 0.39 & 0.24 & 0.27 & 0.68 & 0.27 & 0.21 & 0.38 & 0.31 & 0.35 \\
\hline 12 & TRGB & 0.53 & 0.58 & 1.31 & 3.35 & 0.81 & 1.84 & 3.02 & 0.95 & 0.68 & 0.63 & 0.69 & 1.05 \\
\hline 13 & PKK & 0.51 & 0.54 & 1.54 & 4.61 & 1.00 & 2.42 & 3.47 & 1.38 & 0.87 & 0.65 & 0.92 & 1.25 \\
\hline
\end{tabular}




\begin{tabular}{|c|c|c|c|c|c|c|c|c|c|c|c|c|c|}
\hline 14 & NGR & 0.41 & 0.61 & 1.26 & 1.11 & 0.42 & 0.70 & 1.57 & 0.52 & 0.37 & 0.52 & 0.52 & 0.67 \\
\hline 15 & NAP & 0.54 & 0.58 & 1.18 & 1.13 & 0.43 & 0.59 & 1.33 & 0.53 & 0.39 & 0.50 & 0.47 & 0.65 \\
\hline 16 & VLK & 0.45 & 0.45 & 0.76 & 0.41 & 0.22 & 0.31 & 0.69 & 0.27 & 0.21 & 0.38 & 0.35 & 0.39 \\
\hline 17 & TPI & 0.62 & 0.51 & 1.29 & 2.22 & 0.63 & 1.20 & 1.94 & 0.80 & 0.55 & 0.57 & 0.68 & 0.90 \\
\hline 18 & VKT & 0.53 & 0.53 & 1.25 & 0.57 & 0.34 & 0.40 & 1.17 & 0.40 & 0.31 & 0.49 & 0.41 & 0.54 \\
\hline 19 & VED & 0.67 & 0.49 & 1.31 & 1.24 & 0.48 & 0.79 & 1.59 & 0.63 & 0.43 & 0.50 & 0.47 & 0.72 \\
\hline 20 & KODI & 0.35 & 0.49 & 1.27 & 0.91 & 0.40 & 0.59 & 1.35 & 0.51 & 0.35 & 0.48 & 0.40 & 0.59 \\
\hline \multicolumn{2}{|c|}{ Average } & 0.40 & 0.53 & 1.08 & 1.21 & 0.42 & 0.70 & 1.28 & 0.50 & 0.37 & 0.48 & 0.46 & 0.59 \\
\hline \multicolumn{2}{|l|}{ Cd } & 7.98 & 10.69 & 21.61 & 24.13 & 8.31 & 14.07 & 25.60 & 10.06 & 7.33 & 12.99 & 9.19 & \\
\hline \multicolumn{2}{|c|}{$\mathrm{mcd}$} & 0.66 & 0.89 & 1.80 & 2.01 & 0.69 & 1.17 & 2.13 & 0.84 & 0.61 & 1.08 & 0.77 & \\
\hline
\end{tabular}

From the CF values, considerable contaminations were noticed in the locations like Tharangambadi (TRGB) and Karaikal (PKK) with the values of 3.35 and 4.61 for Ti; 3.02 and 3.47 for $\mathrm{Cr}$ respectively, and also moderate contamination was observed with 1.31 and 1.54 values for $C A ; 1.84$ and 2.42 for the Vin Tharangambadi (TRGB) and Karaikal (PKK) respectively. The locations of Pichavaram (CPM), Tharangambadi (TRGB) and Karaikal (PKK) was not contaminated by $\mathrm{Mg}, \mathrm{K}, \mathrm{Fe}, \mathrm{Mn}, \mathrm{Co}$, $\mathrm{Ni}$ and $\mathrm{Zn}$. Figure $\mathbf{2}$ shows the variation of contamination factor with location.

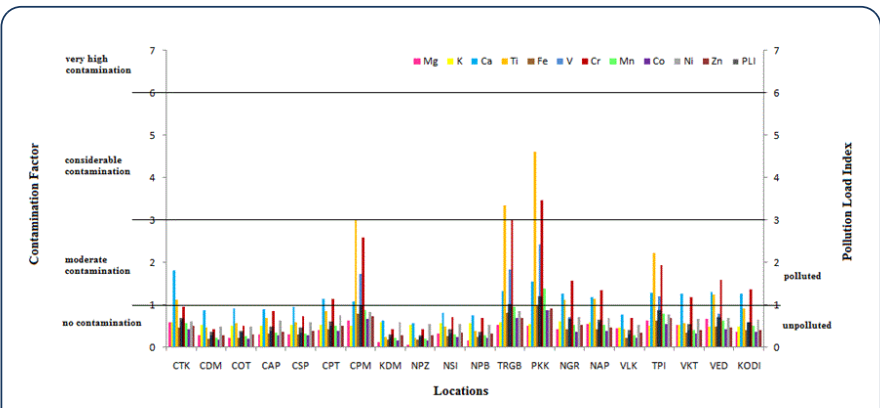

Figure 2: Variation of Contamination factor (CF) and Pollution load index (PLI) in sediment samples of East Coast of Tamilnadu, India.

As seen from Table 4, pollution load index (PLI) ranged from $0.24-1.25$, with mean value 0.59 . PLI value of all sediment samples is less than one except locations of Pichavaram (CPM), Tharangambadi (TRGB) and Karaikal (PKK). This indicates that the sediments are not polluted by heavy metals. The moderately polluted locations of Pichavaram (CPM), Tharangambadi (TRGB) and Karaikal (PKK) in this study may be due to the anthropogenic activities. Figure $\mathbf{2}$ shows the variation of PLI values with different locations.

Table 4 lists the contamination degree $\left(C_{d}\right)$ of sediment samples of the east coast of Tamilnadu, India. The $\mathrm{Cd}$ values of 7.98 for $\mathrm{Mg}$; 10.69 for K; 21.61 for Ca; 24.13 for Ti; 8.31 for Fe; 14.07 for $\mathrm{V} ; 25.60$ for $\mathrm{Cr} ; 10.06$ for $\mathrm{Mn} ; 7.33$ for $\mathrm{Co} ; 12.99$ for $\mathrm{Ni} ; 9.19$ for $\mathrm{Zn}$. Moderate degree of contamination was observed in $\mathrm{Co}, \mathrm{Mg}, \mathrm{Fe}, \mathrm{Zn}, \mathrm{Mn}$ and $\mathrm{Fe}$; $\mathrm{Ni}, \mathrm{V}$ and $\mathrm{Ca}$ shows the considerable degree of contamination; $\mathrm{Ti}$ and $\mathrm{Cr}$ shows high degree of contamination from its value. This may be due to the recent increase in major industrial (in the coastal areas) and a minor harbor activity that involves movement of naval vessels throughout the year may increase the contamination levels in coastal areas. Figure $\mathbf{3}$ shows the variation of $\mathrm{Cd}$ values of heavy metals in locations.

The $\mathrm{mC}_{\mathrm{d}}$ values are between 0.6 and 2.1 for the studied elements. $\mathrm{Cr}$ and $\mathrm{Ti}$ showed $\mathrm{mC}_{\mathrm{d}}$ values $>2$ indicating a moderate degree of contamination (Table 4). From the analysis of $\mathrm{mC}_{\mathrm{d}}$ values indicating that Nil to moderate degree of contamination in study area. Figure $\mathbf{3}$ shows the variation of $\mathrm{mC}_{\mathrm{d}}$ values of heavy metals in locations.

Table 3 reports the potential contamination index $\left(C_{p}\right)$ of sediment samples. The $C_{p}$ values of heavy metals except $\mathrm{Ti}$ shows less than one indicates that the sediments are low contamination. A severe contamination was observed for $\mathrm{Ti}$ (4.609) in the sediments may be due to influence of anthropogenic activities in the study area. Figure $\mathbf{4}$ shows the variation of $C_{p}$ values of heavy metals in locations.

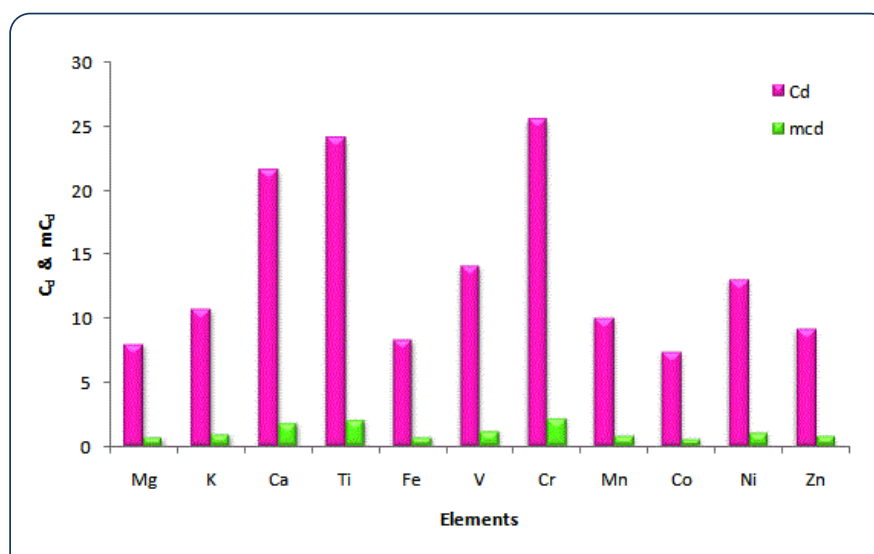

Figure 3: Variation of $C_{d}$ and $\mathrm{mC}_{d}$ of heavy metals in sediment samples of East Coast of Tamilnadu, India. 


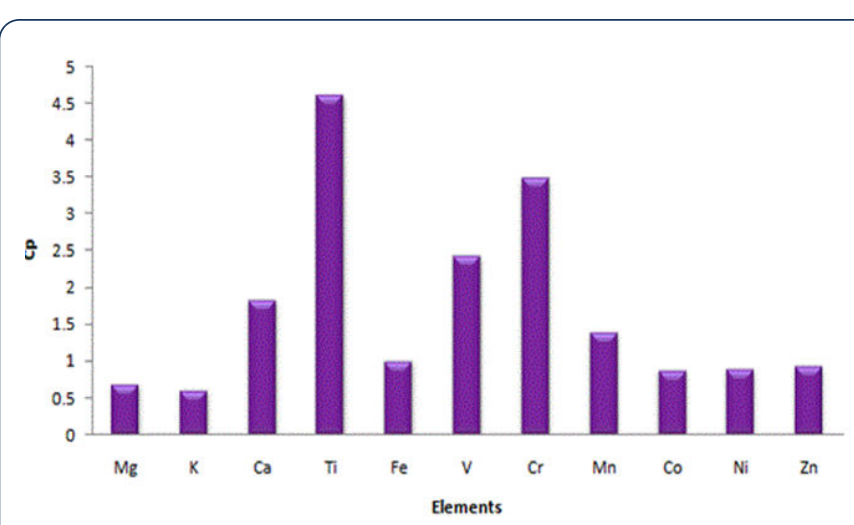

Figure 4: Variation of potential contamination index (Cp) of heavy metals in sediment samples of East Coast of Tamilnadu, India.

As seen from the Table 5, the values of $\mathrm{Cr}, \mathrm{Ni}$ and $\mathrm{Zn}$ found to be less than 40 indicates that the sediments are low potential ecological risk. But potential ecological risk index of $\mathrm{Cr}, \mathrm{Ni}$ and $\mathrm{Zn}$ were less than 95 indicates that low potential ecological risk index (RI). Hence sediments of the present study area showed low potential ecological risk.

\section{Conclusion}

Distribution and ecological risk for $\mathrm{Mg}, \mathrm{Al}, \mathrm{K}, \mathrm{Ca}, \mathrm{Ti}, \mathrm{Fe}, \mathrm{V}, \mathrm{Cr}$, $\mathrm{Mn}, \mathrm{Co}, \mathrm{Ni}$ and $\mathrm{Zn}$ in sediment samples were studied. From the analysis, the sediments are not polluted by $\mathrm{Mg}, \mathrm{Al}, \mathrm{K}, \mathrm{Ca}, \mathrm{Ti}, \mathrm{Fe}$, $\mathrm{V}, \mathrm{Mn}$, Co but slightly enriched with $\mathrm{Cr}, \mathrm{Ni}$ and $\mathrm{Zn}$ due to anthropogenic activities. The locations of Pichavaram (CPM), Tharangambadi (TRGB) and Karaikal (PKK) were found to be moderately polluted by heavy metals due to anthropogenic activities. Heavy metals of $\mathrm{Ti}$ and $\mathrm{Cr}$ are noticed moderately polluted in the sediments of the study area may be due to human activities.

Table 5: Monomial potential ecological risk ( $\mathrm{Er}$ ) factor and potential ecological risk index (RI) values of heavy metals in sediments along the East Coast of Tamilnadu, India.

\begin{tabular}{|l|l|l|l|l|}
\hline \multirow{2}{*}{ S.No. } & \multirow{2}{*}{ Sample ID } & \multicolumn{2}{|l|}{ asdasdas } & Zn \\
\cline { 3 - 5 } & & $\mathbf{C r}$ & $\mathbf{N i}$ & 0.51 \\
\hline 1 & CTK & 1.92 & 3.08 & 0.28 \\
\hline 2 & CDM & 0.86 & 2.42 & 0.30 \\
\hline 3 & COT & 1.01 & 2.39 & 0.36 \\
\hline 4 & CAP & 1.72 & 3.15 & 0.38 \\
\hline 5 & CSP & 1.47 & 2.95 & 0.50 \\
\hline 6 & CPT & 2.26 & 3.74 & 0.73 \\
\hline 7 & CPM & 5.18 & 4.16 & 0.28 \\
\hline 8 & KDM & 0.85 & 2.91 & 0.27 \\
\hline 9 & NPZ & 0.86 & 2.76 & 0.35 \\
\hline 10 & NSI & 1.41 & 2.69 & \\
\hline
\end{tabular}

\begin{tabular}{|l|l|l|l|l|}
\hline 11 & NPB & 1.36 & 2.59 & 0.31 \\
\hline 12 & TRGB & 6.04 & 4.27 & 0.69 \\
\hline 13 & PKK & 6.95 & 4.40 & 0.92 \\
\hline 14 & NGR & 3.14 & 3.56 & 0.52 \\
\hline 15 & NAP & 2.67 & 3.40 & 0.47 \\
\hline 16 & VLK & 1.39 & 2.58 & 0.35 \\
\hline 17 & TPI & 3.88 & 3.89 & 0.68 \\
\hline 18 & VKT & 2.34 & 3.30 & 0.41 \\
\hline 19 & VED & 3.18 & 3.43 & 0.47 \\
\hline 20 & KODI & 2.71 & 3.28 & 0.40 \\
\hline RI & & 51.19 & 64.95 & 9.19 \\
\hline
\end{tabular}

The value of $\mathrm{Cd}$ shows a high degree of contamination for $\mathrm{Ti}$ and $\mathrm{Cr}$ due to the recent increase in major industries and a minor harbor activity in the coastal areas. The overall range of $\mathrm{mCd}$ values indicates a Nil to moderate degree of contamination in the study area. The values of $\mathrm{Cp}$ for all heavy metals show low contamination whereas $\mathrm{Ti}$ shows severe contamination due to the influence of anthropogenic activities in the study area. The result shows that there is no potential ecological risk in the study area. The present work indicated that continuous monitoring and efforts of remediation are may be required to improve the coastal environment near industrialized areas.

\section{Acknowledgement}

We are sincerely thanks and gratitude to Dr. K. K. Satapathy, Head, Environment and Safety Division, RSEG, EIRSG, Indira Gandhi Centre for Atomic Research (IGCAR), Kalpakkam-603 102 for giving permission to make use of EDXRF facility in RSEG and also our deep gratitude and thanks to Dr. M. V. R. Prasad, Head, EnSD, RSEG, IGCAR, Kalpakkam-603102, India for his keen help and constant encouragements in EDXRF measurements. Our sincere thanks to Mr. K.V. Kanagasabapathy, Scientific Officer, RSEG, IGCAR for his technical help in EDXRF analysis.

\section{References}

1. Die'z S, Lacorte S, Viana P, Barcelo D, Bayona JM (2005) Survey of organotin compounds in rivers and coastal environments in Portugal 1999-2000. Environ Poll 136: 525- 536.

2. Maanan M (2008) Heavy metal concentrations in marine molluscs from the Moroccan coastal region. Environ. Poll 153: 176-183.

3. Acevedo-Figueroa D, Jiménez BD, Rodriguez-Sierra CJ (2006) Trace metals in sediments of two estuarine lagoons from Puerto Rico. Environ Pollut 141: 336-342.

4. Maanan M (2007) Biomonitoring of heavy metals using Mytilusgalloprovincialis in Safi coastal waters, Morocco. Environ Toxicol 22: 525-531.

5. Flower RJ, Appleby PG, Thompson JR, Ahmed MH, Ramdani M, et al. (2009) Sediment distribution and accumulation in lagoons 
of the southern Mediterranean region (the MELMARINA Project) with special reference to environmental change and aquatic ecosystems. Hydrobiologia 622: 85-112.

6. BaptistaNeto JA, Smith BJ, McAllister JJ (1999) Sedimentological evidence of human impact on a nearshore environment: Jurujuba Sound, Rio de Janeiro State, Brazil. Appl Geogr 19: 153-177.

7. Bellucci LG, Frignani M, Paolucci D, Ravanelli M (2002) Distribution of heavy metals in sediments of the Venice lagoon: the role of the industrial area. Sci Total Environ 295: 35-49.

8. Patz JA, Daszak P, Tabor GM, Aguirre AA, Pearl M, et al. (2004) Unhealthy landscapes: policy recommendations on land use change and infectious disease emergence. Environ Health Perspect 112: 1092-1098.

9. Pielke RA (2005) Land use and climate change. Science 310 1625-1626.

10. Accornero A, Gnerre R, Manfra L (2008) Sediment concentrations of trace metals in the Berre lagoon (France): an assessment of contamination. Arch Environ Contam Toxicol 54: 372-385.

11. Fang SB, Xu C, Jia XB, Wang BZ, An SQ (2010) Using heavy metals to detect the human disturbances spatial scale on Chinese Yellow Sea coasts with an integrated analysis. J Hazard Mater 184: 375-385.

12. Szefer P, Glassby GP, Pempkowiak J, Kaliszan R (1995) Extraction studies of heavy-metal pollutants in surficial sediments from the southern Baltic Sea off Poland. Chem Geol 120: 111-126.

13. Singh KP, Mohan D, Singh VK, Malik A (2005) Studies on distribution and fractionation of heavy metals in Gomti river sediments- a tributary of the Ganges, India. J Hydrol 312: 14-27.

14. Khaled A, El Nemr A, El Sikaily A (2006) An assessment of heavymetal contamination in surface sediments of the Suez Gulf using geoaccumulation indexes and statistical analysis. Chem Ecol 22 239-252.

15. Long ER, Field LJ, MacDonald DD (1998) Predicting toxicity in marine sediments with numerical sediment quality guidelines. Environ Toxico Chem 17: 714-727.

16. Long ER, Ingersoll CG, MacDonald DD (2006) Calculation and uses of mean sediment quality guideline quotients: a critical review. Environ Sci Tech 40: 1726-1736.

17. Stephen-Pichaimani V, Jonathan MP, Srinivasalu S, RajeshwaraRao N, Mohan SP (2008) Enrichment of trace metals in surface sediments from the northern part of Point Calimere, SE coast of India. Environ Geol 55: 1811-1819.

18. Ravisankar R, Chandramohan J, Chandrasekaran A, Prince PrakashJebakumar J, Vijayalakshmi I, et al. (2015) Assessments of radioactivity concentration of natural radionuclides and radiological hazard indices in sediment samples from the East coast of Tamilnadu, India with statistical approach. Mar Pollut Bull 97: 419-430.

19. Chatterjee M, Silva Filho EV, Sarkar SK, Sella SM, Bhattacharya A, et al. (2007) Distribution and possible source of trace elements in the sediment cores of a tropical macrotidal estuary and their ecotoxicological significance. Environ Int 33: 346-356.

20. Ingham A (Ed.) (1975) Sea Surveying. New York: John Wiley and Sons, pp: 306.

21. Sly PG (1969) Bottom sediment sampling, in Proceedings of the 12th Conference on Great Lakes Research, Buffalo, N.Y. International Association for Great Lakes Research, pp: 883-898.

22. Bryan GW, Langston WJ (1992) Bioavailability, accumulation and effects of heavy metals in sediments with special reference to United Kingdom estuaries: a review. Environ Pollut 76: 89-131.

23. Buchanan JB (1984) Sediment analysis In: Holme NA, Mclntyre $A D$ (Eds.) Methods for the study of marine benthos, Blackwell Scientific Publications, London, pp: 41-65.

24. Langston WJ, Spence SK (1994) Metal analysis In: Calow P (Ed.) Handbook of Ecotoxicology. Oxford Blackwell Scientific Publications, London, pp: 45-78.

25. Ravisankar R, Sivakumar S, Chandrasekaran A, Kanagasabapathy KV, Prasad MVR, et al. (2015) Statistical assessment of heavy metal pollution in sediments of east coast of Tamilnadu using Energy Dispersive X-ray Fluorescence Spectroscopy (EDXRF). App Radia Isot 102: 42-47.

26. Turekian KK, Wedepohl KH (1961) Distribution of the elements in some major units of the Earth's crust. Geol Soc Am Bull 72: 175-192.

27. Hakanson L (1980) An ecological risk index for aquatic pollution control: a sedimentological approach. Water Res 14: 975-100 1.

28. Tomlinson DL, Wilson JG, Harris CR, Jeffrey DW (1980) Problems in the assessment of heavy-metal levels in estuaries and the formation of a pollution index, Helgoland. Mar Res 33: 566-575.

29. Harikumar PS, Nasir UP, Mujeebu Rahman MP (2009) Distribution of heavy metals in the core sediments of a tropical wetland system. Int J Environ Sci Technol 6: 225-232.

30. Abrahim GMS, Parker RJ (2008) Assessment of heavy metal enrichment factors and the degree of contamination in marine sediments from Tamaki Estuary, Auckland, New Zealand. Environ Monit Assess 136: 227-238.

31. Dauvalter V, Rognerud S (2001) Heavy metal pollution in sediments of the Pasvik River drainage. Chemosphere 42: 9-18.

32. Chandramohan J, Chandrasekaran A, Senthilkumar G, Elango G, Ravisankar R (2016) Heavy Metal Assessment in Sediment Samples Collected From Pattipulam to Dhevanampattinam along the East Coast of Tamilnadu Using EDXRF Technique. J Heavy Metal Toxi Disea 1: 1-9. 